\title{
上肢長管骨偽関節に対する創外固定法による治療経験
}

社会保険宮崎江南病院整形外科

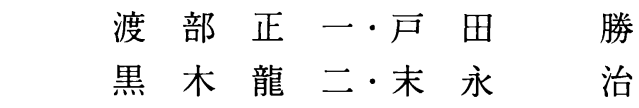

宮崎医科大学整形外科

田島 直 也

\section{External Fixation for Pseudoarthrosis of Upper Extremity Long Bones}

by

\author{
Shoichi Watanabe, Masaru Toda, Ryuji Kuroki \\ and Osamu Suenaga \\ Department of Orthopaedic Surgery, \\ Miyazaki Konan Hospital, Miyazaki Japan \\ Naoya Tajima \\ Department of Orthopaedic Surgery, \\ Miyazaki Medical College
}

\begin{abstract}
Seven patients (five men and two women) diagnosed with pseudoarthrosis of the upper extremity long bones were treated by external fixation. The mean age of patients was 38.3 years (range, 20-55 years). Wagner's fixation was used in five cases, and Mono-Tube in two cases. Bone graft was carried out in 5 cases. As a result, 6 patients acquired bone union, and only 1 patient was not able to achieve union due to bone atrophy and deterioration of bone formation ability. External fixation was effective especially for treating those patients with infectious pseudoarthrosis.
\end{abstract}

Key words : Wagner External Fixator (ワーグナー創外固定器), Mono-Tube External Fixator（モノチューブ創外固定器), Pseudoarthrosis（偽関節）

\section{はじめに}

偽関節の治療法としては従来より髄内釘やプレート 法が多く行われてきたが，近年創外固定を用いた方法 についても報告がみられる．今回我々は，上肢長管骨 偽関節に対して創外固定法を行ったので，若干の考察 を加え報告する。

対

象

1986 年から 1994 年までの 9 年間に, 宮崎医大およ び当科において上肢長管骨偽関節の診断を受け治療さ れた男性 5 例，女性 2 例の計 7 例を対象とした（表 1 ).
年齢は 20 歳から 55 歳（平均 38.3 歳）で, 受傷より 創外固定施行までの期間は 1 年 2 ケ月から 33 年 9 ケ 月 (平均 9 年 10 ケ月).であった。 7 例中 6 例が, 観 血的骨接合術を前医にて施行されていた．部位別では 上腕骨骨幹部 3 例, 上腕骨顆上部 1 例, 橈骨骨幹部が 3 例であり, $\mathrm{AO}$ 分類では肥厚型 6 例, 感染排膿型が 1 例であった。開放性骨折の症例はなかった。

方法

これらの症例に対し，創外固定術および病巣掻爬・ 骨移植術を行った．固定器の機種は Wagner が 5 例, Mono-tube が 2 例で, 骨移植は 5 例に併用した。感 
表 1 症例一覧

\begin{tabular}{|c|c|c|c|c|c|c|c|c|c|}
\hline & 性 & $\begin{array}{l}\text { 年齢 } \\
\text { (齢) }\end{array}$ & 部位 & $\begin{array}{l}\text { 受傷 } \\
\text { 創固定 }\end{array}$ & $\mathrm{AO}$ 分類 & 前医の加療 & 今回の加療 & $\begin{array}{c}\text { 固定期間 } \\
\text { (日) }\end{array}$ & 骨痛合 \\
\hline 1 & M & 40 & $\begin{array}{l}\text { 上腕骨 } \\
\text { 骨幹部 }\end{array}$ & 7 年 & 肥厚型 & プレート & $\begin{array}{l}\text { Wagner } \\
\text { +骨移植 } \\
\end{array}$ & 137 & $(+)$ \\
\hline 2 & $\mathrm{M}$ & 57 & $\begin{array}{l}\text { 上腕骨 } \\
\text { 骨幹部 }\end{array}$ & 20 年 & $\begin{array}{l}\text { 感染 } \\
\text { 排膿型 }\end{array}$ & $\begin{array}{l}\text { プレート } \\
\text { 他 }\end{array}$ & $\begin{array}{l}\text { Mono } \\
\text { tube }\end{array}$ & 130 & $(+)$ \\
\hline 3 & $\mathrm{~F}$ & 46 & $\begin{array}{l}\text { 上腕骨 } \\
\text { 骨幹部 }\end{array}$ & $\begin{array}{l}1 \text { 年 } \\
2 \text { ケ月 }\end{array}$ & 肥厚型 & $\begin{array}{l}\text { プレート } \\
\text { 他 }\end{array}$ & $\begin{array}{l}\text { Wagner } \\
+ \text { 骨移植 }\end{array}$ & (143) & $(-)$ \\
\hline 4 & $\mathrm{~F}$ & 20 & $\begin{array}{l}\text { 上腕骨 } \\
\text { 顆上部 } \\
\end{array}$ & $\begin{array}{l}2 \text { 年 } \\
1 \text { ケ月 }\end{array}$ & 肥厚型 & $\begin{array}{c}\begin{array}{c}\text { Rush ピン } \\
\text { wiring }\end{array} \\
\end{array}$ & $\begin{array}{l}\text { Wagner } \\
+ \text { 骨移植 }\end{array}$ & 354 & $(+)$ \\
\hline 5 & $\mathrm{M}$ & 20 & $\begin{array}{l}\text { 橈骨 } \\
\text { 骨幹部 } \\
\end{array}$ & $\begin{array}{l}1 \text { 年 } \\
7 \text { ケ月 }\end{array}$ & 肥厚型 & プレート & $\begin{array}{l}\text { Wagner } \\
\text { +骨移植 } \\
\end{array}$ & 99 & $(+)$ \\
\hline 6 & M & 55 & $\begin{array}{l}\text { 橈骨 } \\
\text { 骨幹部 }\end{array}$ & $\begin{array}{l}33 \text { 年 } \\
9 \text { ケ月 }\end{array}$ & 肥厚型 & ギプス & $\begin{array}{l}\text { Wagner } \\
+ \text { 骨移植 }\end{array}$ & 167 & $(+)$ \\
\hline 7 & M & 30 & $\begin{array}{l}\text { 橈骨 } \\
\text { 骨幹部 }\end{array}$ & $\begin{array}{l}3 \text { 年 } \\
4 \text { ケ月 }\end{array}$ & 肥厚型 & プレート & $\begin{array}{l}\text { Mono } \\
\text { tube }\end{array}$ & 187 & $(+)$ \\
\hline 平均 & & 38.3 & & $\begin{array}{c}9 \text { 年 } \\
10 \text { ケ月 }\end{array}$ & & & & 179.0 & \\
\hline
\end{tabular}

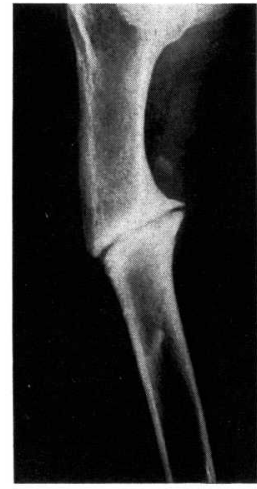

初診時

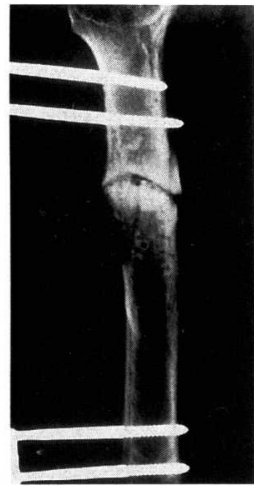

術直後

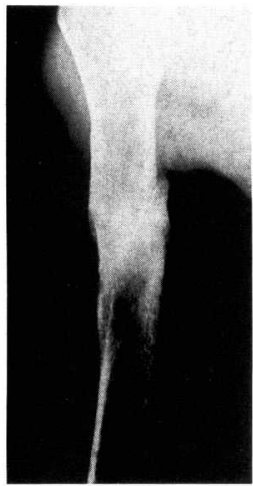

術後 4.5 ケ月

図 1 症例 1.40歳 男性 右上腕骨骨幹部偽関節

染性偽関節の症例には抗生剂を投与し, 病巣掻爬およ び創外固定を施行した。これらについて, 骨癒合の有 無・骨癒合までの期間等について検討を行った.

\section{結果}

ピンのルーズニングを呈した 1 例を除く 6 例に骨癒 合が得られた，創外固定施行より抜釘までの期間は 99 から 354 日, 平均 179.0 日であった。経過中に新 たな感染症や神経麻痺などは出現しなかった。
症例

症例 1.40 歳男性. 主訴, 右上腕部痛.

作業中に落下物が直撃し受傷. 近医にて右上腕骨骨 幹部骨折の診断によりプレート固定され，約 3 ケ月後 に抜釘が行われた，その後より同部の痛みが出現．約 7 年後, 当科受診した. 初診時, 骨折部不安定性およ び肩関節拘縮もあり, 単純 X線にて肥厚型の骨癒合 不全を認めたため, 右上腕骨骨幹部偽関節の診断によ り Wagenr 創外固定および骨移植術を施行した（図 1). 術後 4 ケ月半で骨瘉合良好にて抜釘した. 術前の 


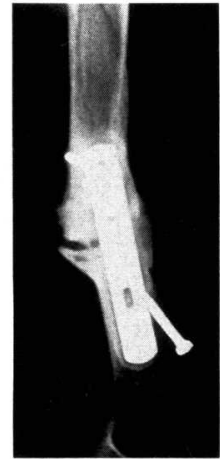

初診時単純 X 線

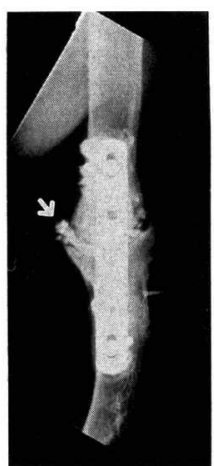

瘦孔造影

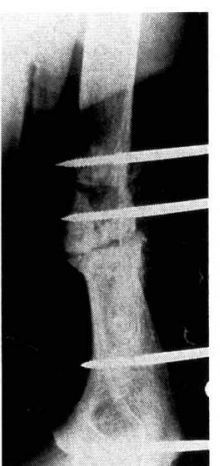

術直後

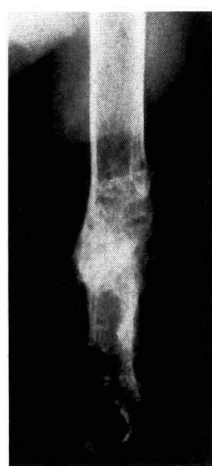

術後 4.5 ケ月

図 2 症例 2.57歳 男性 左上腕骨骨幹部偽関節

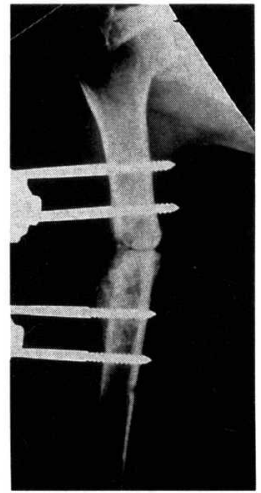

術直後

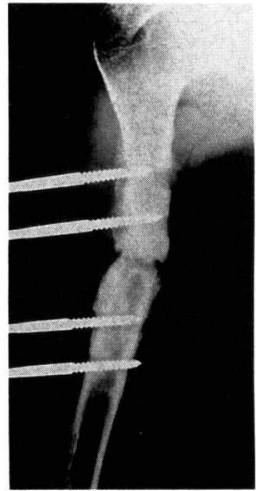

術後 5 ケ月

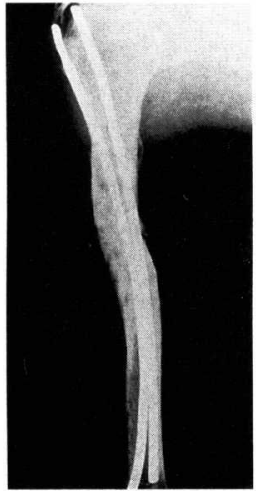

Ender 術後 14 ケ月

図 3 症例 3.46歳 女性 右上腕骨骨幹部偽関節

肩関節拘縮は改善し，时関節可動域制限も生じなかっ た. 現在, 営業業務に復帰している。

症例 2. 57 歳男性. 主訴, 左上腕部痛.

交通事故にて受傷. 近医にて左上腕骨骨幹部骨折の 診断によりプレート固定をはじめ数回の手術を受けた. 19 年後, 誘因なく創部痛が出現し, 滲出液が排出し てきたため当科受診した。初診時, 創部に㾇孔と㾇孔 からの排膿がみられた。血液検査にて WBC : 9100 , CRP : 16.0, 膿培養では Staphylococcusaureus が 検出された。単純 X 線では上腕骨骨幹部に肥厚型の 骨癒合不全が, 瘻孔造影では骨折部に造影剂の充満を 認めた（図 2). 左上腕骨骨幹部偽関節および化膿性 骨髄炎の診断により直ちに広域抗生剂投与開始し, 抜
釘・污染部掻爪巴およびMono-tube を使用した創外固 定術を施行した．治療開始 2 週後の血液検査にて白血 球および CRP は正常化し，培養も陰性となった。術 後より骨癒合促進電気刺激装置（オステオトロン II） を 1 日 8 時間で約 4 ケ月使用した. 術後約 4 ケ月半で 創外固定除去. 現在肘関節屈曲 120 度, 伸展 -20 度 で回内. 回外制限はない. 現在, 現職に復帰している.

考察

創外固定は, 1855 年に Langenbeckにより始まり, 近年, Hoffmann や井上 ${ }^{4)} に よ り$ 改善が加えられ広 く用いられている. 従来より主に開放性骨折や多発骨 折に用いられてきた ${ }^{216)}$ が，近年その適応が徐々に拡 
大されつつある゙3(5)6).

一般的な長所として, 手術侵襲が少なく骨折部軟部 組織の損傷が軽度, 骨折部に異物を留置しない, 手抜 が比較的簡単で抜釘も容易等 ${ }^{4)}$ が挙げられる.

上腕骨骨幹部は本来骨瘉合良好な部位といわれる が, 一度骨癒合が遷延すると非常に難治性となる ${ }^{8)}$. 今回我々は上腕骨骨幹部偽関節を 3 例経験したが， 1 例はピンのルーズニングを生じ抜釘した（図 3). 原 因としては, 頻回の骨接合術による周辺正常軟部組織 の減少，また慢性関節リウマチの合併による骨脆弱性 が考えられた。この症例はその後エンダー法により骨 癒合を獲得した。

上腕骨顆上部ではピンの刺入位置が問題となるが, 大野らの方法"を用いることにより安全に固定を得る ことができた。

また，前腕骨はプレート法の発達により偽関節自体 の発生が少なくなったと考えられるが, プレート術後 に偽関節を生じると, 骨の細さ故にプレートによる再 手術は行いにくく，創外固定の適応になると考えられ た。

当科では，上肢長管骨偽関節における創外固定の適 応を次のように考えている. (1)骨欠損を有する偽関節 で, 特に感染性偽関節. (2)骨端部偽関節. ただし, 術 後管理を徽底することが肝要である。

$$
\text { ま と め }
$$

(1)上肢長管骨偽関節に対する創外固定法による治療
経験について報告した.

(2) 7 例中 6 例に骨瘉合を得た，骨瘉合を獲得できな かった 1 例は，骨脆弱性拉よび骨形成能低下が原因で あると考えられた。

(3)上肢骨偽関節，特に感染性偽関節に対する治療法 として, 創外固定法は非常に有用である.

\section{参 考 文 献}

1）赤掘 治, 原 靖隆, 工藤展也: 上腕骨偽関節. 整形 外科 MOOK, $22: 153-162,1982$.

2) Cooney, W.P., Smith, D. K.: External fixation of the upper extremity. AAOS instructual course rectures, $36: 455-467,1987$.

3）穂茠行貴, 益山宏幸, 小山新太郎ら：上腕骨骨幹部骨 折に対する創外固定法の適応と限界. 日本創外固定研究 会誌, $4: 73-76,1993$.

4) 井上四郎：偽関節の治療 - 創外固定. 整形外科 MOOK, $22: 64-94,1982$.

5）小口光昭, 井上四郎, 大橋俊郎ら：上腕骨骨折に対す るレジン創外固定法の使用経験. 日本創外固定研究会誌, $2: 1-4,1991$.

6）西山 誠, 大川 徹, 松岡宏昭ら：創外固定を使用し た感染性長管骨骨折の治療経験. 日本創外固定研究会誌, $5: 11-15,1994$.

7）大野博史, 安井夏生, 柑本春夫ら：上腕骨に対する創 外固定法. 日本創外固定研究会誌, $3: 1-6,1992$.

8）大植 睦, 安部宗昭, 土井宗算ら : 創外固定のみで骨 愈合が得られた上腕骨偽関節の 2 例. 日本創外固定研究 会誌, $5: 161-164,1994$. 